\title{
Cold-Blooded Vertebrates at the Proposed Reference Repository Location in Southeastern Washington
}

\author{
R. E. Fitzner
}

January 1988

Prepared for the U.S. Department of Energy under Contract DE-AC06-76RLO 1830

Pacific Northwest Laboratory Operated for the U.S. Department of Energy by Battelle Memorial Institute 


\title{
DISCLAIMER
}

This report was prepared as an account of work sponsored by an agency of the United States Government. Neither the United States Government nor any agency thereof, nor Battelle Memorial Institute, nor any of their employees, makes any warranty, expressed or implied, or assumes any legal liability or responsibility for the accuracy, completeness, or usefulness of any information, apparatus, product, or process disclosed, or represents that its use would not infringe privately owned rights. Reference herein to any specific commercial product, process, or service by trade name, trademark, manufacturer, or otherwise, does not necessarily constitute or imply its endorsement, recommendation, or favoring by the United States Government of any agency thereof, or Battelle Memorial Institute. The views and opinions of authors expressed herein do not necessarly state or reflect those of the United States Government or any agency thereof, or Battelle Memorial Institute.

\author{
PACIFIC NORTHWEST LABORATORY \\ operated by \\ BATTELLE MEMORIAL INSTITUTE \\ for the \\ UNITED STATES DEPARTMENT OF ENERGY \\ under Contract DE-ACO6-76RLO 1830
}

Printed in the United States of America
Available from
National Technical Information Service
United States Department of Commerce
5285 Port Royal Road
Springfield, Virginia 22161
NTIS Price Codes
Microfiche A01
Printed Copy
Pages
$001-025$
$026-050$


PNL -6440

UC-11

COLD-BLOODED VERTEBRATES

AT THE PROPOSED REFERENCE

REPOSITORY LOCATION IN

SOUTHEASTERN WASHINGTON

R. E. Fitzner

January 1988

Prepared for

the U.S. Department of Energy

under Contract DE-ACD6-76RLO 183D

Pacific Northwest Laboratory

Richland, Washington 99352 


\section{PREFACE}

In 1986, the U.S. Department of Energy (DOE) selected the Hanford Site in southeastern Washington for further study as a permanent repository for commercial spent nuclear fuel and high-level radioactive waste. The DOE then initiated a site characterization program to obtain the information necessary for evaluating the suitability of locating a repository at the Hanford Site. These characterization activities are part of the Basalt Waste Isolation Project (BWIP). Pacific Northwest Laboratory (PNL) was contracted by the DOE to do the environmental studies. The DOE is required by Section 113(a) of the Nuclear Waste Policy Act (NWPA) to "conduct site characterization activities in a manner that minimizes any significant adverse environmental impacts identified . . ."

Because the site characterization program requires underground testing, clearing of the land surface, and other activities that may impact the environment, the Office of Civilian Radioactive Waste Management developed an Environmental Monitoring and Mitigation Plan (EMMP) to document compliance with Section 113(a) of the NWPA. The EMMP is to provide an overview of programs to be used for detecting potentially significant adverse environmental impacts resulting from site characterization, as identified in consultation with the affected states and Indian tribes. Additional information on technical approaches is provided in the Environmental Field Activity Plans (EFAPs) for EMMP-mandated programs.

This document is part of the Environmental Topical Report series. These topical reports, presenting the results of the environmental monitoring studies at the BWIP site, will be issued intermittently as specific project objectives are met. Topical reports will be a reference source for other BWIP environmental reports, including the 6-month EMMP reports, EWIP Environmental Reviews, and environmental licensing reports. 



\section{SUMMARY}

The information in this interim report will be used to design future environmental monitoring $\mathrm{plans}$ and assess impacts related to Basalt Waste Isolation Project (BWIP) activities. New reports will be issued as more data become available.

Five study locations were established to study cold-blooded vertebrates in the vicinity of the proposed Reference Repository Location. Four study sites were in shrub-dominated stands of vegetation; the other site was devoid of shrubs because of a range fire in 1984. The side-blotched lizard (Uta stansburiana), trapped in four of the five plots, was the only lizard species captured. It was not trapped in the one plot dominated by spiny hopsage (Grayia spinosa) shrubs. It is uncertain whether the side-blotched lizard is absent from this particular vegetation type, or if the population is too low to have been detected in the relatively short time span of the investigation.

Two species of snakes were captured, gopher snakes (Pituophis melanoleucus) and green racers (Coluber constrictor mormon). The number of snakes captured was too small to detect any distributional pattern in space or time. Studies are continuing. 

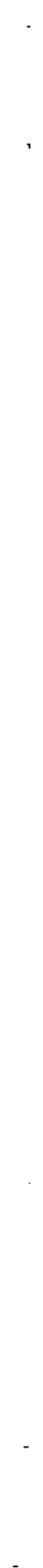


\section{CONTENTS}

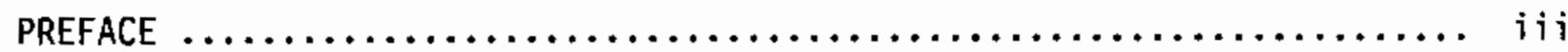

SUMMARY $\ldots \ldots \ldots \ldots \ldots \ldots \ldots \ldots \ldots \ldots \ldots \ldots \ldots \ldots \ldots \ldots \ldots \ldots \ldots \ldots \ldots \ldots$

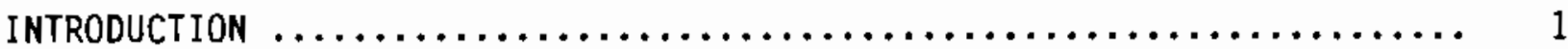

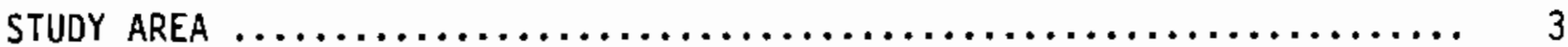

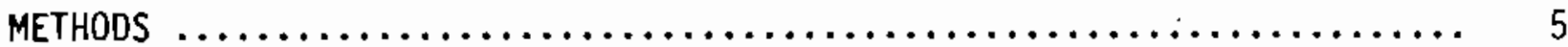

SELECTION OF STUDY PLOTS $\ldots \ldots \ldots \ldots \ldots \ldots \ldots \ldots \ldots \ldots \ldots \ldots \ldots \ldots \ldots$

SAMPLING METHODOLOGIES $\ldots \ldots \ldots \ldots \ldots \ldots \ldots \ldots \ldots \ldots \ldots \ldots \ldots \ldots \ldots$

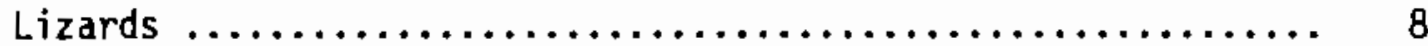

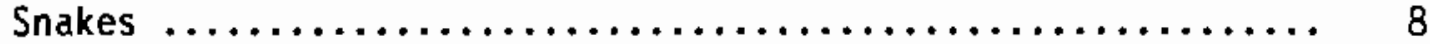

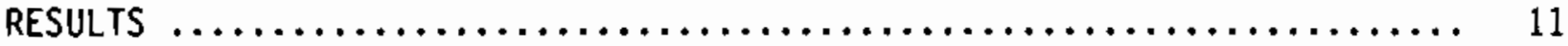

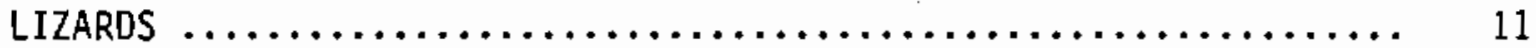

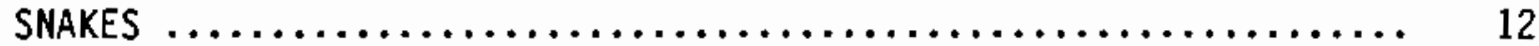

ENDANGERED, THREATENED, AND SENSITIVE SPECIES $\ldots \ldots \ldots \ldots \ldots \ldots \ldots \ldots . . \ldots$

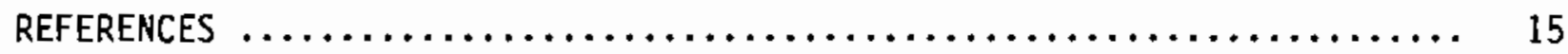



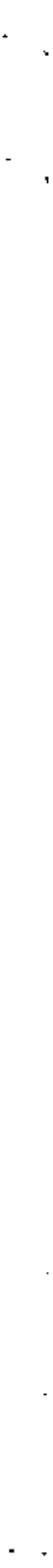

. 


\section{FIGURES}

1 Cold-Blooded Vertebrate Study Plots at the Proposed Reference Repository Location in Southeastern Washington ......... 3

2 Study Plot 1: A Sagebrush/Bluegrass Vegetation Association ...... 5

3 Study Plot 2: A Spiny Hopsage Vegetation Association .......... 6

4 Study Plot 3: A Sagebrush/Bluegrass Vegetation Association ....... 6

5 Study Plot 4: A Sagebrush/Bluegrass Vegetation Association ....... 7

6 Study Plot 5: A Burned Area, Now Dominated by Cheatgrass, Sandberg Bluegrass, and Tumble Mustard (Sisymbrium Altissimum) .... 7

7 Pitfall Sampling Station for Trapping Lizards ............... 9

8 Drift Fence and Wire Cage Used for Trapping Snakes ........... 9

$9 \quad$ Side-Blotched Lizard $\ldots \ldots \ldots \ldots \ldots \ldots \ldots \ldots \ldots \ldots \ldots \ldots \ldots \ldots \ldots \ldots$

\section{TABLES}

1 Individual Side-Blotched Lizards Captured at Five Study Plots at the Proposed Reference Repository Location in Southeastern Washington in Two 3-Day Periods in July and August $1986 \ldots \ldots \ldots \ldots 12$

2 Individual Snakes Captured at Three Study Locations at the Proposed Reference Repository Location in Southeastern

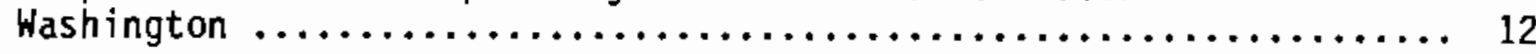

3 State Sensitive Reptiles Known to Occur on the Hanford Site....... 14 
. 


\section{INTRODUCTION}

Cold-blooded vertebrates (lizards, snakes, and amphibians) are residents of shrub-steppe vegetation on the Hanford Site. However, there is virtually no information on their spatial and temporal distribution patterns. The response of cold-blooded vertebrates to the vegetation-damaging impacts created by drill pad and roadway construction and other activities is virtually undocumented.

This interim report summarizes the results of the initial trapping efforts made in the late summer and early fall of 1986. See Rickard (1987) for additional background information and for a map of the Hanford Site. 



\section{STUDY AREA}

The area studied is about $8 \mathrm{~km}^{2}$ of undeveloped semiarid land located around the Exploratory Shaft (Figure 1). The natural vegetation has been described by Rickard (1987). Sagebrush (Artemisia tridentata) is the dominant shrub, but spiny hopsage is locally dominant in a small area approximately $1.5 \mathrm{~km}$ west of the Exploratory Shaft. Much of the natural shrub-steppe vegetation has been burned in recent years. Fire destroys sagebrush and spiny hopsage, but the understory grasses, especially cheatgrass (Bromus tectorum) and Sandberg bluegrass (Poa sandbergii), recover in the next growing season after a summer burn.
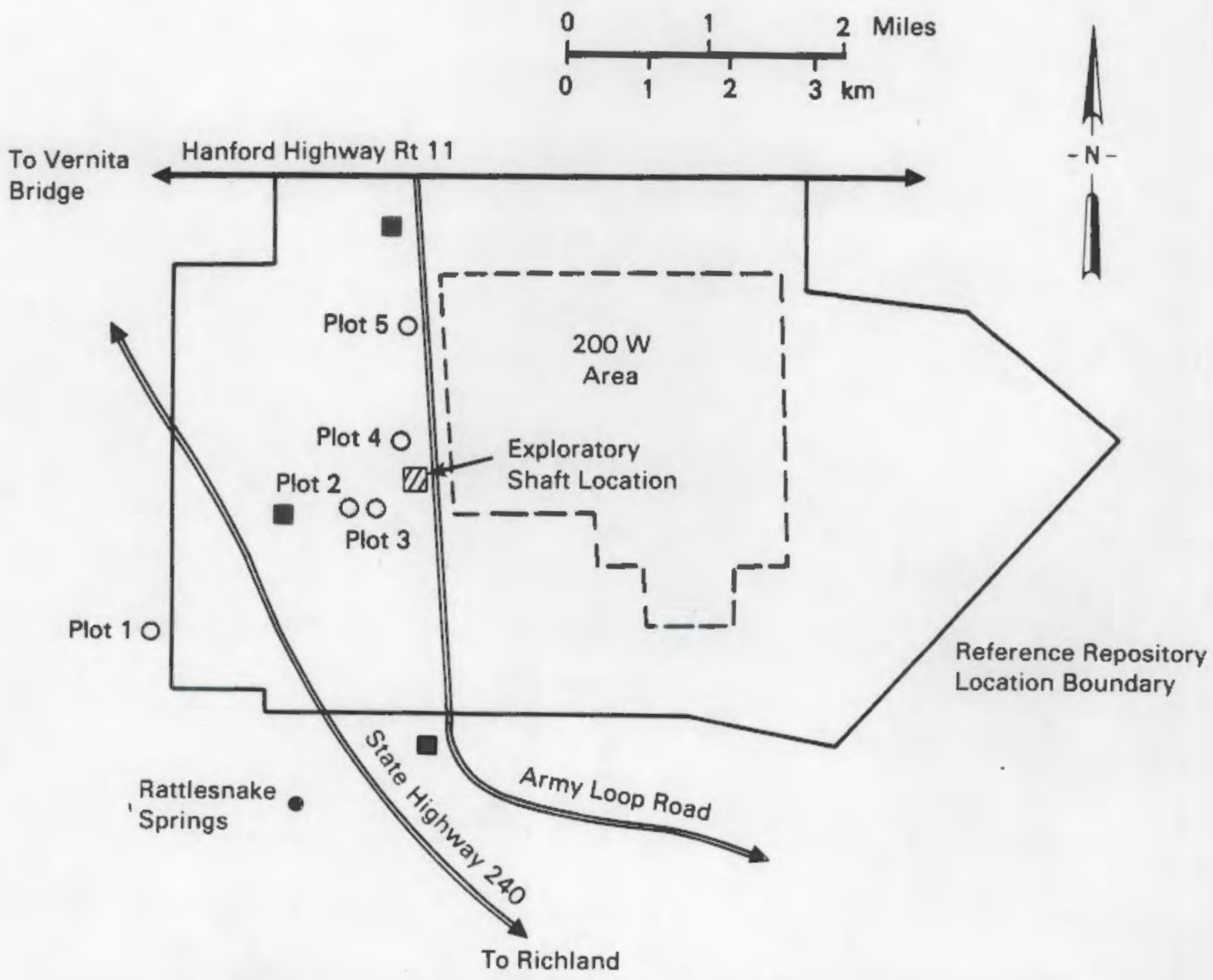

FIGURE 1. Cold-Blooded Vertebrate Study Plots at the Proposed Reference Repository in Southeastern Washington 



\section{METHODS}

\section{SELECTION OF STUDY PLOTS}

Study plots were selected in the spring of 1986 . The plots are located in the same general areas as Rickard's (1987) vegetational analysis plots. Rickard selected five locations for vegetational characterization and permanently marked all plots so they could be relocated. Plots labeled 1S, $3 \mathrm{~S}, 4 \mathrm{~S}$, and $5 \mathrm{~S}$ are dominated by sagebrush, while $2 \mathrm{H}$ is dominated by spiny hopsage. Four of the five cold-blooded vertebrate study plots (Plots 1, 2, 3 , and 4) are adjacent to Rickard's Plots $1 \mathrm{~S}, 2 \mathrm{H}, 3 \mathrm{~S}, 4 \mathrm{~S}$, respectively. Plot 5 was placed in an area burned in 1984. Figure 1 provides a map of the coldblooded vertebrate study plots. Figures 2, 3, 4, 5, and 6 are photographs of the habitat at each of the five plots.

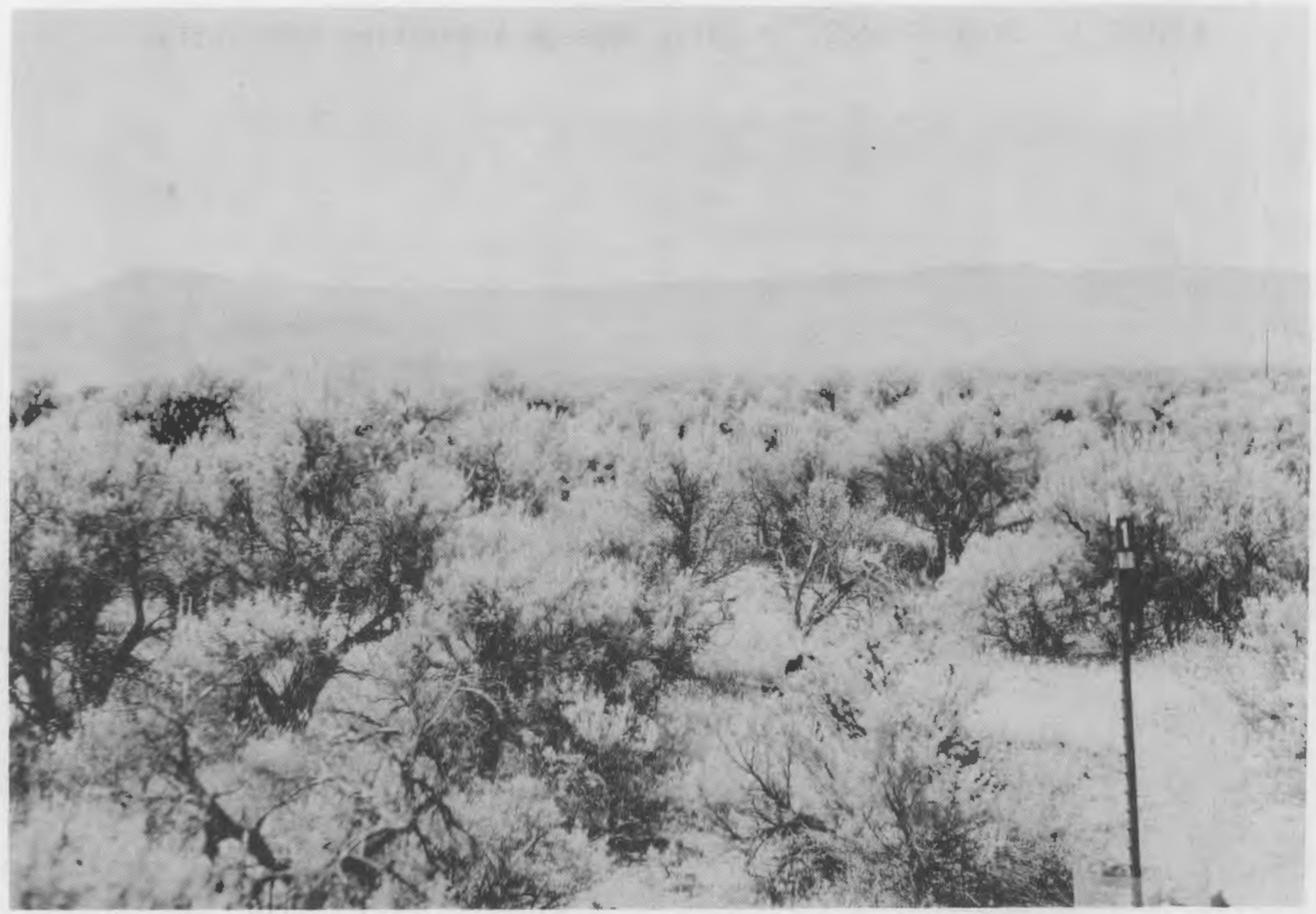

FIGURE 2. Study Plot 1: A Sagebrush/Bluegrass Vegetation Association 


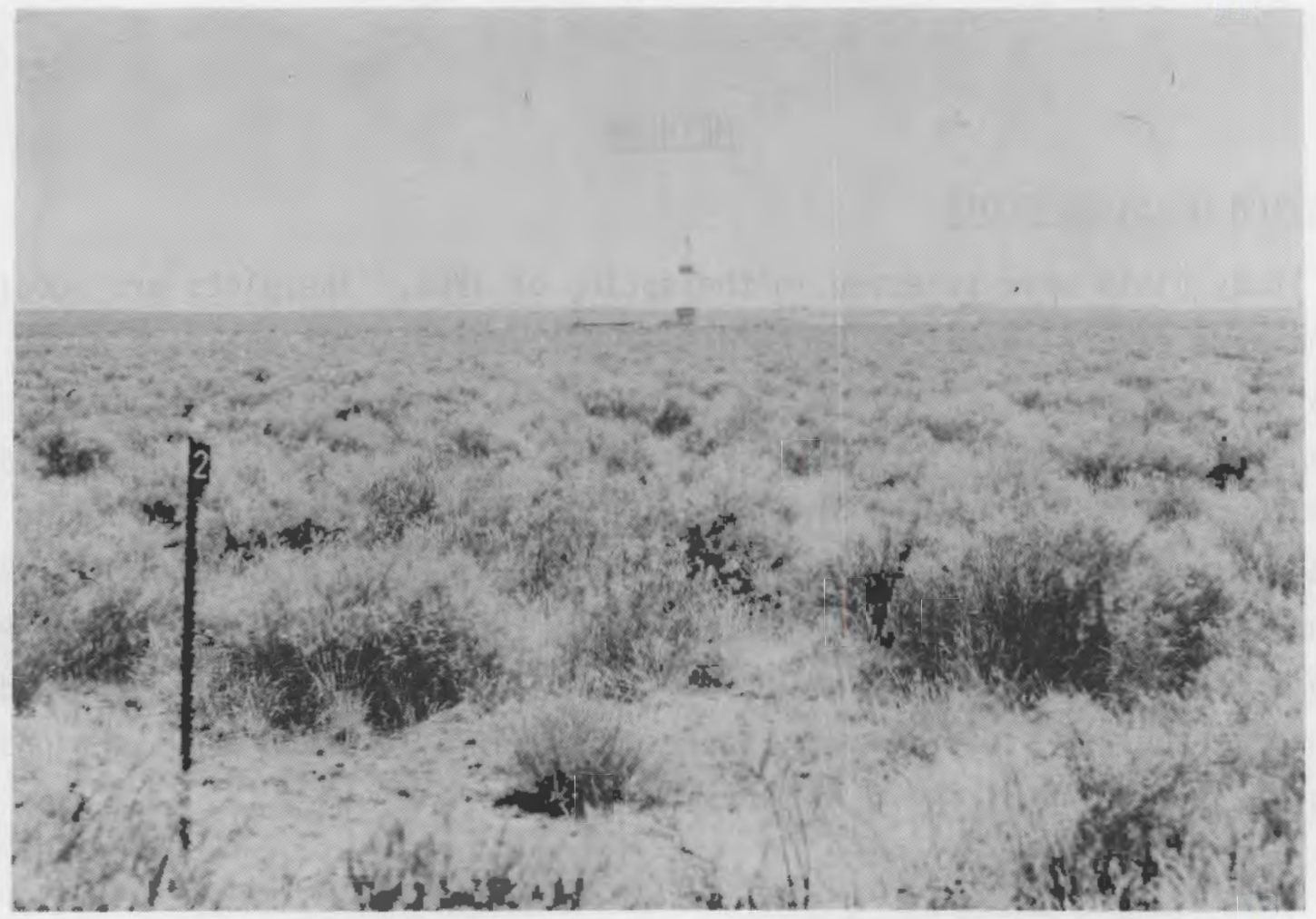

FIGURE 3. Study Plot 2: A Spiny Hopsage Vegetation Association

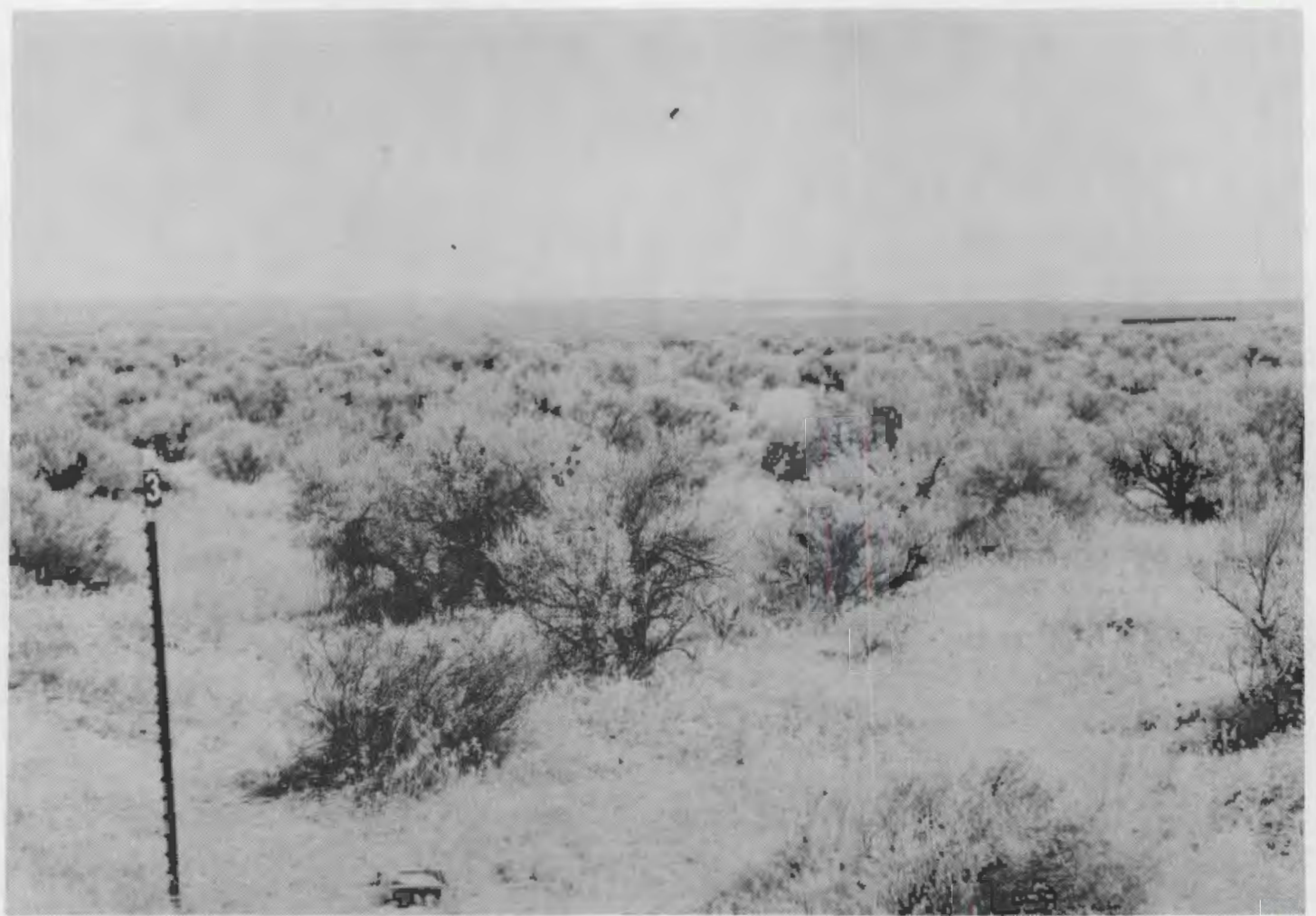

FIGURE 4. Study Plot 3: A Sagebrush/Bluegrass Vegetation Association 


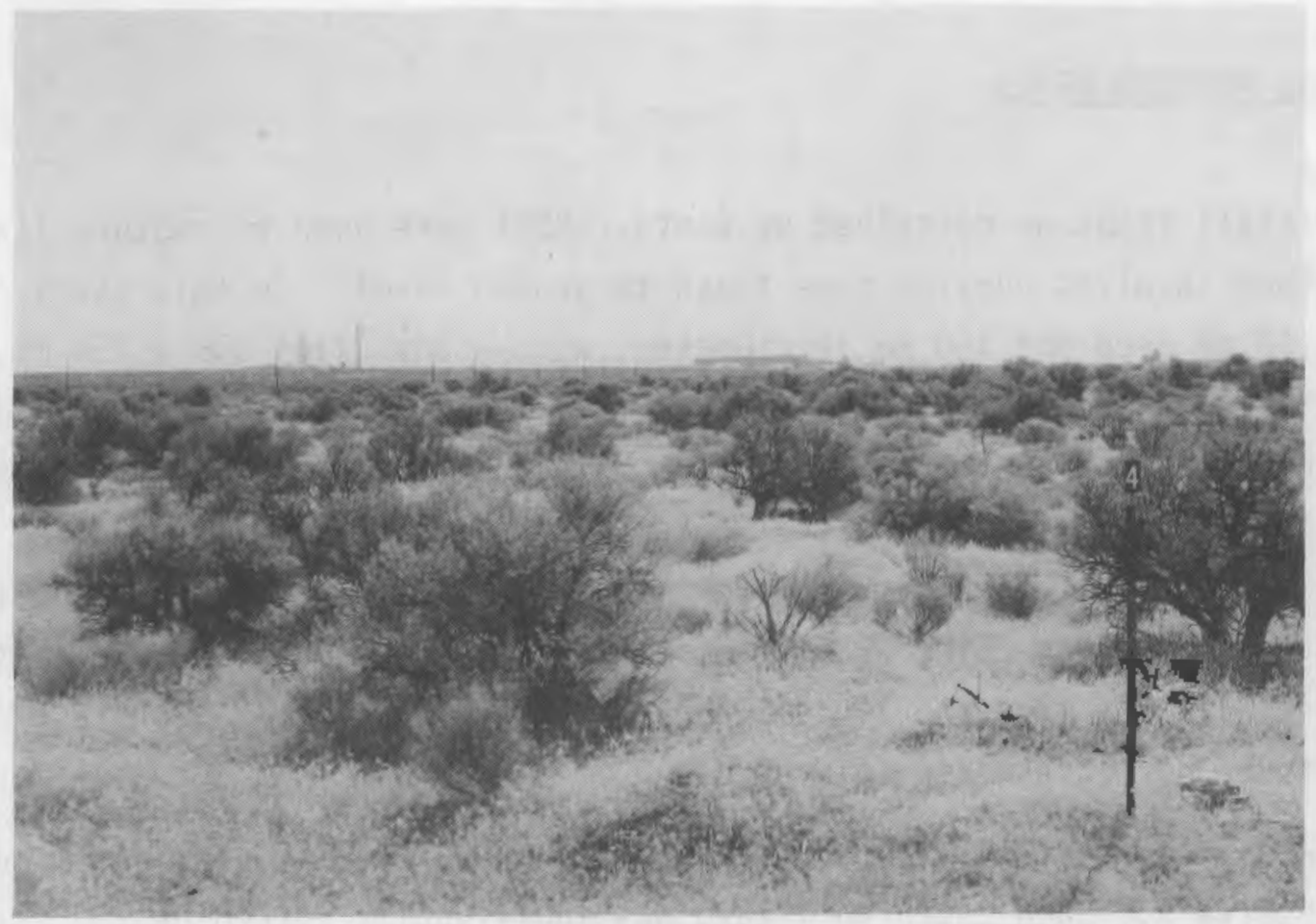

FIGURE 5. Study Plot 4: A Sagebrush/Bluegrass Vegetation Association

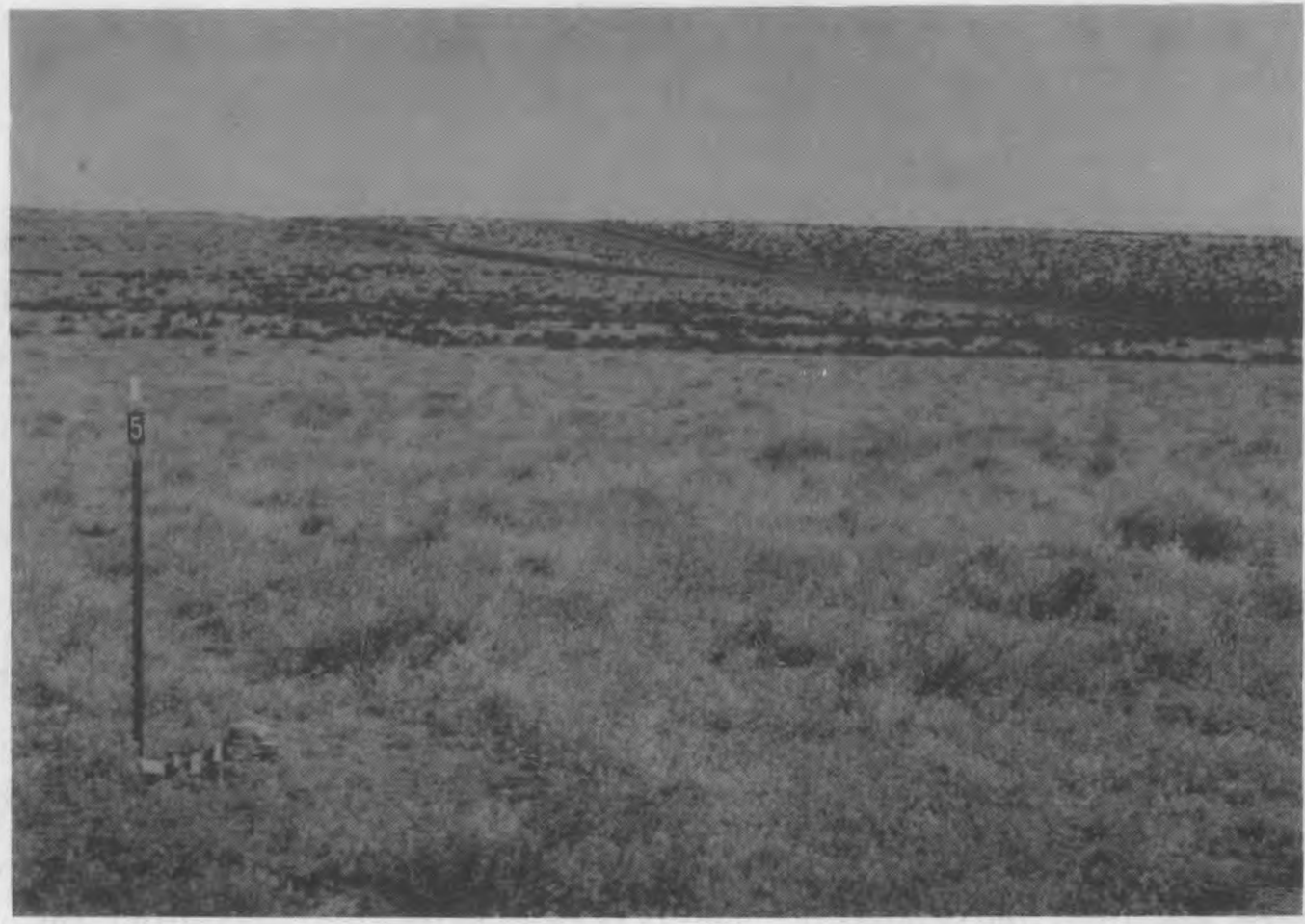

FIGURE 6. Study Plot 5: A Burned Area, Now Dominated by Cheatgrass, Sandberg Bluegrass, and Tumble Mustard (Sisymbrium Altissimum) 


\section{SAMPLING METHODOLOGIES}

\section{Lizards}

Pitfall traps as described by Banta (1957) were used to capture lizards. The method involves burying cans flush to ground level. In this study, round cans, $155 \mathrm{~mm}$ deep and $150 \mathrm{~mm}$ in diameter, with wooden lids $203 \times 254 \mathrm{~mm}$, were placed over each can. The covers have 2.3- $\times 2.3-$ tnm strips of wood nailed to their bottoms to elevate them slightly while they shade the pitfall cans. When the pitfalls are closed, the wooden covers are turned over and the flat side allowed to sit tight against the lip of the pitfall can. A stone is placed on the wooden cover when the pitfall can is closed to ensure that animals and wind will not move the lid off the pitfall. Figure 7 is a photograph of a pit trap and lid used in this study.

Twenty-five pitfall traps were placed in a $5 \times 5$ grid $(40 \times 40 \mathrm{~m})$ at 10-m intervals. Each captured lizard was individually marked by toe clipping and released near the point of capture. Each of the five toes on a foot was assigned a number from 1 to 5 (left to right). Unmarked feet received a 0 . This method provides 1,296 possible toe-clip combinations. Lizards were weighed with a $10-g$ capacity Pesola scale.

\section{Snakes}

Wire drift fences in conjunction with wire cages were used to capture snakes. This method was first described by Dargan and Stickel (1949), but the method used in the present study has been modified slightly from the original design (Figure 8 ). We constructed $61-\mathrm{m}$-1ang drift fences of 6.4-mm hardware cloth, $457 \mathrm{~mm}$ high. The fences have a $0.61-\times 1.22-\mathrm{m}, 457-\mathrm{mm}-\mathrm{high}$ cage on each end and one in the middle. The tops and bottoms of the cages are constructed of 19-mm plywood and the sides are 6.4-mm hardware cloth. The end traps have two funnels for channeling the snakes into the cage and the center trap has one funnel.

Captured snakes were removed from the cage and weighed with a $300-g-c a p a c-$ ity Pesola scale. Snakes were measured in millimeters for total length. Each snake was then individually identified by injecting tattooing ink under one or more of its ventral scales. The anal scale was counted as 0 , each 
ventral scale from the anal scale to the head was consecutively numbered starting with 1 , and the number of the marked scale recorded.

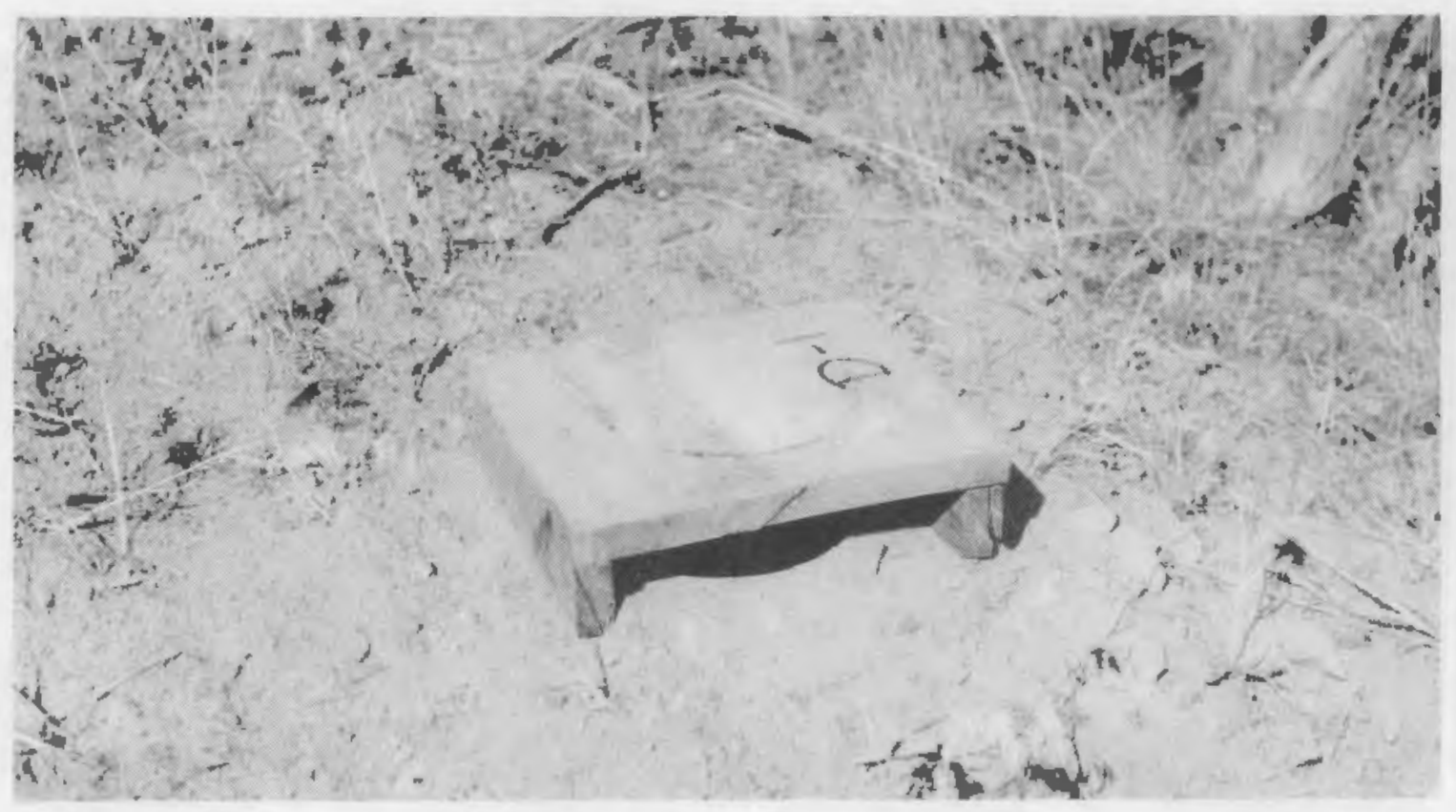

FIGURE 7. Pitfall Sampling Station for Trapping Lizards

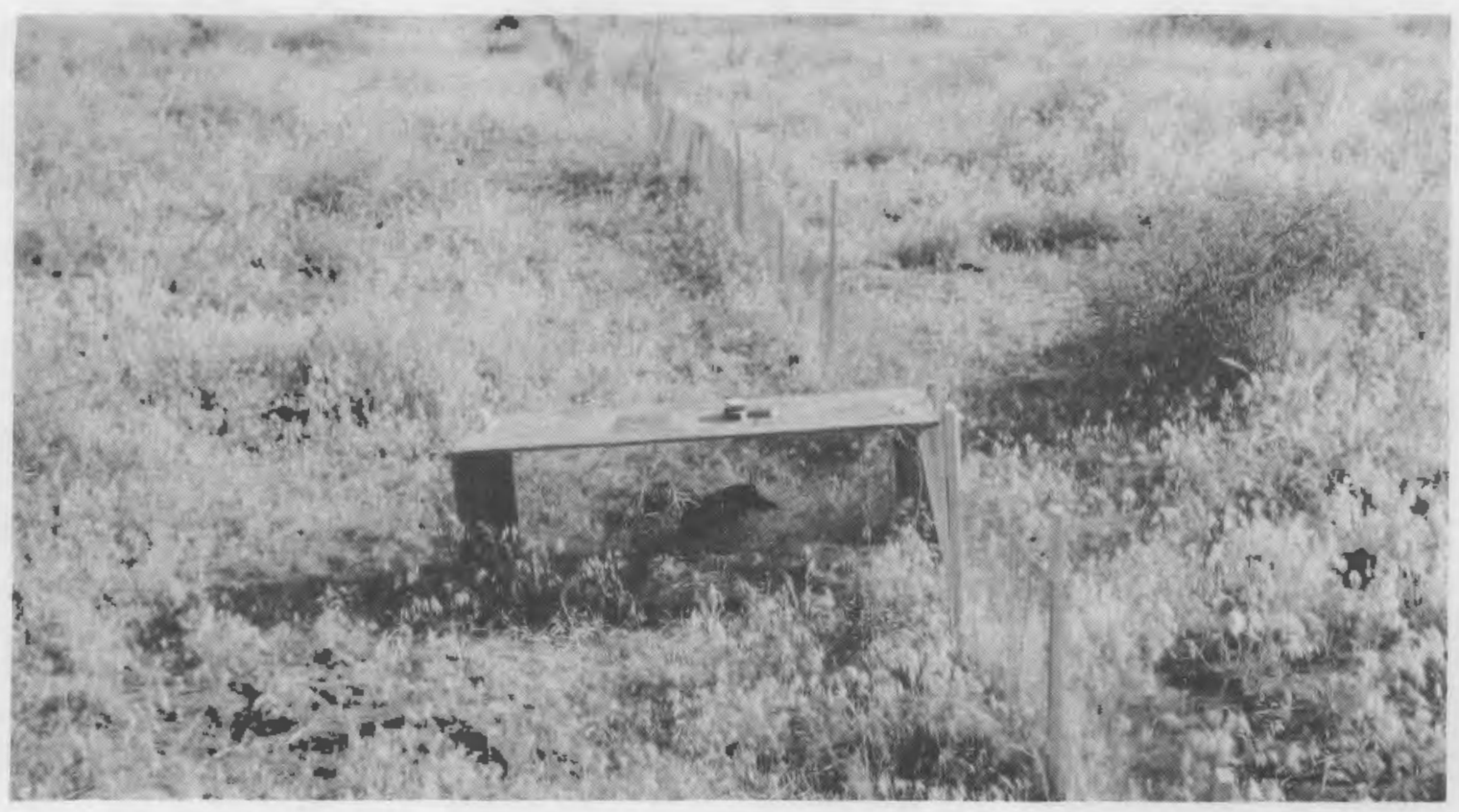

FIGURE 8. Drift Fence and Wire Cage Used for Trapping Snakes 


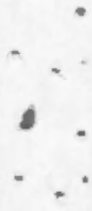




\section{RESULTS}

\section{LIZARDS}

The results of the pitfall trapping are summarized in Table 1. In all, 28 individual side-blotched lizards (Figure 9) were captured and marked, 16 females and 12 males (Table 1 ). Nineteen of the 28 animals were captured in Plot 1; only four lizards were captured in the burned plot, but this was greater than the two and three captures for Plots 3 and 4, respectively. No lizards were captured in Plot 2, the hopsage-dominated plot.

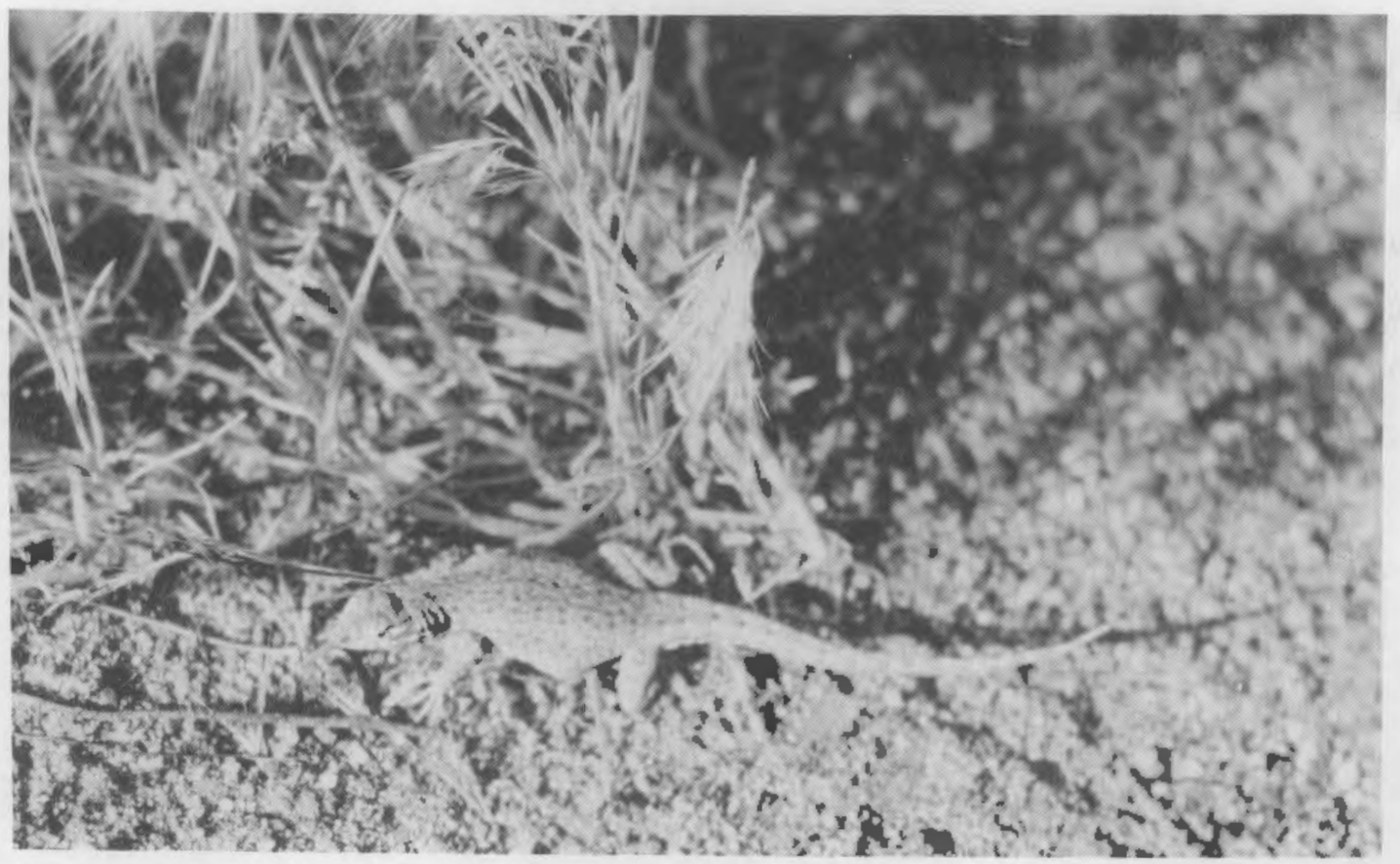

FIGURE 9. Side-Blotched Lizard 
TABLE 1. Individual Side-Blotched Lizards Captured at Five Study Plots at the Proposed Reference Repository Location in Southeastern Washington in Two 3-Day Periods in July and August 1986

\begin{tabular}{|c|c|c|c|c|c|c|}
\hline & $\begin{array}{c}\text { Plot } 1 \\
\text { (s) }\end{array}$ & $\begin{array}{l}\text { Plot } 2 \\
\text { (h) }\end{array}$ & $\begin{array}{c}\text { Plot } 3 \\
\text { (s) }\end{array}$ & $\begin{array}{c}\text { Plot } 4 \\
\text { (s) } \\
\end{array}$ & $\begin{array}{l}\text { Plot } 5 \\
\text { (sb) }\end{array}$ & Total \\
\hline Total Catch & 19 & 0 & 2 & 3 & 4 & 28 \\
\hline Females & 9 & 0 & 2 & 2 & 3 & 16 \\
\hline Males & 10 & 0 & 0 & 1 & 1 & 12 \\
\hline
\end{tabular}

$s=$ sagebrush; $h=$ hopsage; $s b=$ sagebrush burned .

\section{SNAKES}

The results of trapping for snakes are summarized in Table 2. Only six individuals were captured, three gopher snakes and three green racers (Table 2). The catch was too small to make any judgment concerning the abundance of snakes at the RRL; however, studies are continuing.

TABLE 2. Individual Snakes Captured at Three Study Locations at the Proposed Reference Repository Location in Southeastern Washington

\begin{tabular}{lccccc}
\multicolumn{1}{c}{ Species } & Plot 1 & & Plot 2 & Plot 3 & Total \\
\cline { 1 - 1 } Gopher Snake & 0 & & 2 & 1 & 3 \\
Green Racer & 1 & 0 & 2 & 3
\end{tabular}

\section{ENDANGERED, THREATENED, AND SENSITIVE SPECIES}

No federally classified endangered or threatened cold-blooded vertebrates are known to occur on the Hanford Site. There are, however, several species listed by the state of Washington as "special animal species" (Washington Department of Game 1983). The state has a number of classifications it uses for these species: 
SE State Endangered. A species seriously threatened with extirpation throughout all or a significant portion of its range within Washington. These species are classified by the State Game Commission as Endangered Wildlife (WAC 232-12-014), and are protected from taking, taking due to damage (RCH 77.12.265), trafficking (RCW 77.16.040), and taking, possession, control, or destruction of nests or eggs (RCW 77.16.120).

PE Proposed Endangered. A species proposed for state Endangered classification.

ST State Threatened. A species that could become endangered within Washington without active management or removal of threats. These species are classified by the State Game Commission as Protected Wildlife (WAC 232-12-011). They are protected from taking, possession, and control, and destruction of nests or eggs (RCW 77.16.120).

PT Proposed Threatened. A species proposed for state Threatened classification.

SS State Sensitive. A species that could become Threatened if current water, land, and environmental practices continue. They are classified by the State Game Commission as Protected Wildlife (WAC 232-12-011), and are protected from taking, possession, control, and destruction of nests or eggs (RCW 77.16.120).

PS Proposed Sensitive. A species proposed for state Sensitive classification.

SM Monitor Species. A species of special interest because it: 1) has significant popular appeal; 2) requires limited habitat during some portion of its life cycle; 3 ) is an indicator of environmental quality; 4) requires further field investigations to determine population status; 5) has unresolved taxonomic problems that may bear upon status classification; or 6) was justifiably removed from endangered, threatened, or sensitive classification.

PM Proposed Monitor. A species proposed for state Monitor classification.

Only. five cold-blooded vertebrates known to occur on the Hanford Site occur on the State list (Table 3). None of these species were observed in any of the study areas. There is, however, high probability that some or all of these species occur on or adjacent to the proposed repository. 
TABLE 3. State Sensitive Reptiles known to Occur on the Hanford Site

$\begin{array}{ll}\text { Species } & \text { State } \\ \text { Status }\end{array}$

Sagebrush lizard

(Sceloporus graciosus)

Northern desert horned lizard

(Phrynosoma platyrhinos)

Striped whipsnake

(Masticophis taeniatus)

Night snake

(Hypsiglena torquata)

Woodhouse's toad

(Bufo woodhousei)
PM Areas of sagebrush and gravel soils or fine-sand dunes

PM Areas of sandy, gravelly soil, wind blown sand, flat arid stretches where rocks or scrub vegetation are present

PM Grassland and arid brushy flatland

PM Semiarid and arid sandy or rocky situations. From plains and desert flats to heavy brush

PM Sandy areas near marshes, irrigation ditches, backyards, temporary raiл pools

Ongoing and future studies will focus on locating these species and documenting their occurrence on the Hanford Site by sampling a wider variety of habitats, over a larger area, with greater intensity. 


\section{REFERENCES}

Rickard, W. H. 1987. Interim Report: Natural Vegetation at the Proposed Reference Repository Location in Southeastern Washington. PNL-6402, Pacific Northwest Laboratory, Richland, Washington.

Banta, B. H. 1957. "A Simple Trap for Collecting Desert Reptiles." Herpetologica $13(3): 174-176$.

Dargan, L. M., and W. H. Stickel. 1949. "An Experiment with Snake Trapping." Copeia (4):264-268.

Washington Department of Game. 1983. Washington State Special Animal Specjes, 0lympia, Washington. 
. 


\section{DISTRIBUTION}

No. of

Copies

\section{OFFSITE}

10 DOE/Office of Scientific and Technical Information

ONSITE

21 DOE Richland Operations office

J. J. Sutey

S. C. Whitfield (20)

\section{Pacific Northwest Laboratory}

A. K. Baldwin (20)

P. A. Beedlow

C. A. Brandt

J. C. Chatters

C. Cluett

D. D. Dauble

D. W. Dragnich

L. E. Eberhardt

D. H. Fickeisen

R. E. Fitzner (5)

M. J. Graham

J. M. Hales

P. C. Hays

S. E. King

S. M. McCorquodale

N. V. Marr

R. L. Newell

T. L. Page

L. D. Poole

W. H. Rickard, Jr.

C. A. Schuler

J. B. States

J. A. Stottlemyre

S. L. Thorsten

R. E. Wildung

S. G. Weiss

Publishing Coordination (2)

Technical Report Files (5) 
.
.
-
- 